\title{
ECOLOGICAL AND PHYSIOLOGICAL PERFORMANCE OF WHITE BEAN (PHASEOLUS VULGARIS L.) AFFECTED BY ALGAE EXTRACT AND SALICYLIC ACID SPRAYING UNDER WATER DEFICIT STRESS
}

\author{
Beigzadeh, S. ${ }^{1}-$ MALeKI, A. ${ }^{*}-$ Heydari, M. M. ${ }^{1}-$ KhOURgami, A. ${ }^{2}-$ RAngin, A. ${ }^{3}$ \\ ${ }^{1}$ Department of Agronomy and Plant Breeding, College of Agriculture, Islamic Azad University \\ Ilam Branch, Ilam, Iran \\ (e-mail:Sepantasbkf.b686@gmail.com;maleki97@yahoo.com; mirzaeiheydari@yahoo.com)
}

${ }^{2}$ Department of Agronomy, Khoramabad Branch, Islamic Azad University, Lorestan, Iran (e-mail: Ali_khorgamy@yahoo.com)

${ }^{3}$ Department of Biology, Islamic Azad University, Ilam Branch, Ilam, Iran

(e-mail: alireza1121sar@gmail.com)

*Corresponding author

e-mail:maleki97@yahoo.com

(Received $13^{\text {th }}$ Jul 2018; accepted $31^{\text {st }}$ Oct 2018)

\begin{abstract}
In order to investigate the effects of salicylic acid and seaweed extract foliar on photosynthetic pigments of white bean grown under water deficit stress, a split-split plot experiment was conducted based on randomized complete block design with three replicates. The experimental factors consisted of irrigation regimes at three levels, seaweed extract at four levels and salicylic acid foliar application at two levels. In both places of the experiment, application of $150 \mathrm{~g} \cdot \mathrm{ha}^{-1}$ seaweed extract along with salicylic acid increased leaf relative water content in plants grown under water deficit stress. The maximum chlorophyll a content $\left(15.15 \mathrm{mg} \cdot \mathrm{g}^{-1} \mathrm{FW}\right)$ was observed when $150 \mathrm{~g} \cdot \mathrm{ha}^{-1}$ seaweed extract was applied under no water deficit stress condition. By contrast, the minimum chlorophyll a content $\left(8.34 \mathrm{mg} \cdot \mathrm{g}^{-1} \mathrm{FW}\right)$

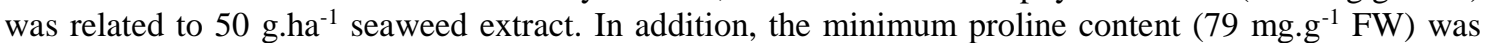
found when no salicylic acid foliar was applied under water deficit stress. However, the maximum proline content (123.2 mg.g ${ }^{-1} \mathrm{FW}$ ) was obtained when $100 \mathrm{~g} \cdot \mathrm{ha}^{-1}$ from seaweed extract was applied under severe water deficit stress. The results indicated that the maximum seed yield $\left(2343.3 \mathrm{~kg} \mathrm{ha}^{-1}\right)$ was achieved when 100 g.ha ${ }^{-1}$ seaweed extract was applied and there was no water deficit stress.
\end{abstract}

Keywords: anthocyanin, proline, seed yield, RWC, total chlorophyll

\section{Introduction}

Protein deficiency in diet causes several problems for human health. Besides animal proteins, plant proteins such as legumes are also an important source of proteins. With growing population in the world, protein requirement and consumption of plant resources are increasing. Among various crops, beans are used as one of the most important and valuable sources of plant proteins (Hosseini, 2008) and have been used in human diet for centuries. Beans are a rich source of protein (20-30\%) and carbohydrates (50-60\%) and a relatively good source of minerals and vitamins (Rehman and Shah, 2004). In most parts of the world, water is a limiting factor for agricultural productions. Drought stress is one of the major threats to successful crop production across the world. Drought stress reduces crop yield by $50 \%$ or more (Bai et al., 2006). According to the FAO reports (2010), around 90\% of Iran with arid and semi-arid climate conditions is covered with sparse vegetation. 
One of the effects of environmental stresses is lipid peroxidation (Bai et al., 2006) and degradation of proteins and nucleic acids (Kovacik et al., 2014).

Salicylic acid is a phenolic compound known as a plant hormone or growth regulator, which plays a key role in defense mechanisms against biotic and abiotic stress factors including drought tolerance. It has a significant role in reducing oxidative damage caused by different stresses in plants and developing an anti-stress mechanism in plant cells. Studies have shown that, under drought stress conditions, salicylic acid improves plant growth, transpiration, stomatal regulation, photosynthesis and ion absorption and transfer (Hayat and Ahmad, 2007). Algae have been used to reduce physiological disturbances caused by mineral deficiency and thus improved grain production and resistance to frost (Sridhar and Rengasamy, 2011). In addition to supplying nitrogen and mineral elements, algae regulate plant growth by releasing plant regulating hormones. The presence of plant hormones such as auxin, gibberellin and cytokinin has been shown in the extract of brown algae. Therefore, application of seaweed extract as a fertilizer, increases the growth and production of plants (Erulan et al., 2009). Inorganic extract of $A$. nodosome contains nitrogen, phosphorus, potassium, calcium, iron, magnesium, zinc, sodium and sulfur. Various types of seaweeds stimulate different responses of plants for example, increase in yield, increase in nutrients uptake, changes in the composition of plant tissues, increase in cold resistance, increase in pathogen resistance and increase in fruits quality and germination rate (Sridhar and Rengasamy, 2011). Seaweed extract is produced by hydrolysis under high pressure, however the process differs from species to species. The final concertation of the extract depends on its use as high concentrations could be harmful for plants. Seaweed extract is suitable for those products in which growth hormones such as IAA, IBA, cytokinins, vitamins and amino acids are used (Kaoaua et al., 2013). This study was conducted to investigate the effects of seaweed extract and salicylic acid on white bean performance, grown under water deficit stress condition.

\section{Materials and Methods}

The current study was carried out to investigate the effects of salicylic acid and seaweed extract foliar application on photosynthetic pigments, biochemical characteristics and yield of white bean (Phaseolus vulgaris L.) grown under water deficit stress condition in the Agricultural Research Station, Khorramabad, Iran, in 2016 and 2017 growing seasons. The soil characteristics, meteorology data and geographical location of the study site are presented in Tables 1 and 2.

The experiments were conducted as a split-split plot experiment based on a randomized complete block design with three replicates. The experimental factors consisted of irrigation regimes (main plots) at three levels, (irrigation after 60 (no water deficit stress), 90 (mild water deficit stress) and $120 \mathrm{~mm}$ (severe water deficit stress) evaporation from class A evaporation pan), seaweed extract (Ascophyllum nodosum) (sub-plots) at four levels (0, 50, 100 and $\left.150 \mathrm{~g}^{\mathrm{h}} \mathrm{ha}^{-1}\right)$ and salicylic acid foliar application (sub-sub plots) at two levels (with and without). Chlorophyll a, b and total chlorophyll were measured according to Porra method (Porra, 2002). Anthocyanins and carotenoids were measured based on the methods described by Lichtenthaler and Wellburn (1983). Leaf samples $(500 \mathrm{mg}$ ) were rest in $5 \mathrm{ml} 80 \%$ acetone and centrifuged at $13000 \mathrm{rpm}$ at 4 ${ }^{\circ} \mathrm{C}$ for $15 \mathrm{~min}$. The supernatant made up to $10 \mathrm{ml}$ with $80 \%$ acetone and used for spectrophotometry. 
Table 1. Soil physicochemical properties

\begin{tabular}{c|c|c|c|c|c|c|c|c|c}
\hline Depth & $\begin{array}{c}\text { Total N } \\
(\boldsymbol{\%})\end{array}$ & $\begin{array}{c}\text { P(AVO) } \\
\text { P.P.M. }\end{array}$ & $\begin{array}{c}\text { K(AVO) } \\
\text { P.P.M. }\end{array}$ & $\begin{array}{c}\text { C.E.C. } \\
\text { Meq/mg }\end{array}$ & $\begin{array}{c}\text { Neutralized } \\
\text { percentage }\end{array}$ & $\mathbf{p H}$ & $\mathbf{E C} * \mathbf{1 0}$ & $\begin{array}{c}\text { Saturation } \\
\text { percentage } \\
\text { s.p. }\end{array}$ & $\begin{array}{c}\text { Organic } \\
\text { carbon } \\
\text { O.C\% }\end{array}$ \\
\hline $0-20$ & 13 & 9.2 & 640 & 30.8 & 15.2 & 7.6 & 0.73 & 54 & 1.26 \\
$60-20$ & 6 & 2.8 & 380 & 30.2 & 17.5 & 7.7 & 0.49 & 55 & 0.63 \\
$95-60$ & 3 & 2.4 & 240 & 28.0 & 24.5 & 7.8 & 0.44 & 52 & 0.29 \\
$125-95$ & 4 & 2.8 & 220 & 28.0 & 26.0 & 7.8 & 0.48 & 51 & 0.38 \\
\hline
\end{tabular}

Table 2. Meteorological and geographical properties of the study site

\begin{tabular}{c|c|c|c|c|c|c}
\hline Longitude & Latitude & Altitude & $\begin{array}{c}\text { Average } \\
\text { annual rainfall }\end{array}$ & $\begin{array}{c}\text { Average } \\
\text { temperature }\end{array}$ & $\begin{array}{c}\text { Absolute max } \\
\text { temperature }\end{array}$ & $\begin{array}{c}\text { Absolute min } \\
\text { temperature }\end{array}$ \\
\hline $47^{\circ} 26^{\prime}$ & $34^{\circ} 8^{\prime}$ & $1346 \mathrm{~m}$ & $538 \mathrm{~mm}$ & $10.5^{\circ} \mathrm{C}$ & $41^{\circ} \mathrm{C}$ & $-28.8^{\circ} \mathrm{C}$ \\
\hline
\end{tabular}

Different types of leaf chlorophyll amount were determined based on Arnon (1949) approach. Leaf samples of $0.1 \mathrm{~g}$, from each experimental unit (pots) were obtained from youngest leaves. Samples were grounded and placed in $10 \mathrm{ml}$ of $80 \%$ acetone. Resulting extract was centrifuged in $3000 \mathrm{rpm}$ for 10 minutes and the obtained supernatant was placed in cuvette. The absorbance of the solution was recorded by spectrophotometry at 645 and $663 \mathrm{~nm}$ wavelengths. Arnon equations were used to estimate the chlorophyll a and $\mathrm{b}$ as below:

$$
\begin{gathered}
\text { Cholorophyll a }(\mathrm{mg} / \mathrm{ml})=[(12 / 7 \times \mathrm{A} 663)-(2 / 69 \times \mathrm{A} 645)] \\
\text { Cholorophyll b }(\mathrm{mg} / \mathrm{ml})=[(22 / 9 \times \mathrm{A} 645)-(4 / 68 \times \mathrm{A} 663)] \\
\text { Cholorophyll a+b }(\mathrm{mg} / \mathrm{ml})=\text { Chla }+ \text { Chlb })) \\
\text { Carotenoid }(\mu \mathrm{g} / \mathrm{ml})=(1000(\mathrm{~A} 470)-1.8(\text { Chla })-85.02(\mathrm{Chlb})) / 198
\end{gathered}
$$

Proline content was determined using Bates et al. (1973) method. Briefly, $500 \mathrm{ml}$ leaf sample was placed in $10 \mathrm{ml}$ of $3 \%$ sulfosalicylic acid and then the homogenate was filtered using filter paper. Then $2 \mathrm{ml}$ of the sample was mixed with $2 \mathrm{ml}$ ninhydrin acid (25.1 g ninhydrin plus $30 \mathrm{ml}$ glacial acetic acid) and $2 \mathrm{ml}$ glacial acetic acid in test tubes. The test tubes were heated at $100{ }^{\circ} \mathrm{C}$ for $1 \mathrm{~h}$ and then cooled down at $4{ }^{\circ} \mathrm{C}$ for 30 min before adding $4 \mathrm{ml}$ toluene. The samples were vortexed and left on the bench for 10 min. The upper layer was used for spectrophotometry at $520 \mathrm{~nm}$. The following equations were used to calculate proline content.

$$
\begin{array}{r}
\left.\frac{\mu g}{m L} \text { Proline } \times m L \text { toluene }\right) \times \frac{\mu m o l}{115 / 5 \mu g} \times \frac{5}{\text { sample } g}=\mu \text { molproline per } g \text { fresh sample (Eq.5) } \\
\left(\frac{\mu g}{m L} \text { Proline } \times m L \text { toluene }\right) \times \frac{5}{\text { sample } g}=\mu g \text { proline per } g \text { fresh sample }
\end{array}
$$

The relative water content was determined using (Diaz-Perez et al., 2006) method. Young leaves were detached and equal leaf discs were prepared and then weighted (fresh weight). The discs were soaked in distilled water for $24 \mathrm{~h}$ and weighed again to 
determine saturated weight. Finally, the samples were dried in an oven for $48 \mathrm{~h}$ to determine dry weight. The relative water content was calculated according to the following equation.

$$
\mathrm{RWC}=(\mathrm{FW}-\mathrm{DW}) /(\mathrm{TW}-\mathrm{DW}) * 100
$$

where: $F_{w}$ : fresh weight, $D_{w}$ : dry weight and $T_{w}$ saturated weight.

Leaf electrolytes leakage was measured according to Flint (1967). Equal leaves were taken and then were cut into discs. The discs were washed using distilled water and then put into tests tubes containing $5 \mathrm{ml}$ deionized distilled water. After $24 \mathrm{~h}$, the electrical conductivity (EC) of the samples was measured using EC meter (Jenway, 4010). To assess the photosynthetic pigments quartz spectrometer cell (UV_160A_SHIMADO model, made in Japan) was used. Electrical conductivity Multi-range (model H18733) was used to measure the EC. The samples were put in the freezer at $-20 \mathrm{C}$ for another 24 $\mathrm{h}$ and then the EC was measured again. The value of electrical leakage was calculated using the following equation:

$$
\frac{E c_{1}}{E c_{2}} \times 100
$$

Before exposing data to ANOVA and statistical analysis, SPSS was used to perform test for errors and data normality. Data were analyzed by SPSS as split-plot factorial based on randomized complete block design and Duncan's test was used for mean comparison. Interactive effects of means were signified by Duncan's test by using MSTATC app and MS Excel was used for plots.

\section{Results and Discussion}

This study results indicated that the effects of water deficit stress, seaweed extract, and salicylic acid foliar applications were significant on all the studied traits. However, none of the traits were affected by place. Although the interaction between each factor and place was not significant, all interaction between experimental factors was significant. The interaction between place and other experimental factors was only significant on RWC.

\section{Relative Water Content (RWC)}

The results showed that main effects of water deficit stress, seaweed extract, and salicylic acid were significant on RWC. Significate interactions are shown in Table 3. The results indicated the minimum RWC $(36.41 \%)$ was due to mild water deficit stress and salicylic foliar application treatment in the first place. In addition, in both sites of the experiment, salicylic acid increased RWC under severe water deficit stress condition and seaweed extract application. Salicylic acid seems to increase the RWC through the ability of the plant to maintain the leaf water potential. It has been reported that spraying salicylic acid during flowering would increase the RWC, osmotic potential and leaf turgidity (Hussain et al., 2008). Ramroudi and Khamar (2013) showed increase of RWC in basil by application of salicylic acid. 
Table 3. Analysis of variance on bean traits

\begin{tabular}{|c|c|c|c|c|c|c|c|c|c|c|}
\hline $\begin{array}{l}\text { Source of } \\
\text { variation }\end{array}$ & df & Carotenoid & Anthocyanin & $\begin{array}{c}\text { Total } \\
\text { chlorophyll }\end{array}$ & Chlorophyll a & Chlorophyll b & $\begin{array}{c}\text { Electrolyte } \\
\text { leakage }\end{array}$ & RWC & proline & yield \\
\hline$(\mathrm{P})$ place & 1 & $32.3 \mathrm{~ns}$ & $1995.4 \mathrm{~ns}$ & $20.1 \mathrm{~ns}$ & $0.702 \mathrm{~ns}$ & $10.2 \mathrm{~ns}$ & $4.8 \mathrm{~ns}$ & $160.4 \mathrm{~ns}$ & $45.6 \mathrm{~ns}$ & $985.4 \mathrm{~ns}$ \\
\hline$(\mathrm{r} / \mathrm{P})$ & 4 & 57.6 & 410.2 & 5.7 & 0.665 & 2.71 & 33.8 & 47.1 & 76.5 & 546.4 \\
\hline $\mathrm{a}$ & 2 & $437.3 * *$ & $1434.9 \mathrm{~ns}$ & $208.8 * *$ & $11.9 * *$ & $101.7 * *$ & $1508.2 * *$ & $2941.5^{* *}$ & $567.78 * *$ & $409.5^{* *}$ \\
\hline $\mathrm{P} \times \mathrm{a}$ & 2 & $2.5 \mathrm{~ns}$ & $1304.8 \mathrm{~ns}$ & $1.8 \mathrm{~ns}$ & $0.994 \mathrm{~ns}$ & $10.5 \mathrm{~ns}$ & $3.4 \mathrm{~ns}$ & $16.8 \mathrm{~ns}$ & $6.5 \mathrm{~ns}$ & $909.5 \mathrm{~ns}$ \\
\hline error & 8 & 3.74 & 478.6 & 2.30 & 0.432 & 1.60 & 44.1 & 22.8 & 7.87 & 321.4 \\
\hline $\mathrm{b}$ & 3 & $37.4 *$ & $1054.5 * *$ & $194.8 * *$ & $13.2 * *$ & $112.6 * *$ & $693.3 * *$ & $3138.4 * *$ & $43.0 * *$ & $1209.5 * *$ \\
\hline $\mathrm{P} \times \mathrm{b}$ & 3 & $7.38 \mathrm{~ns}$ & $2.147 \mathrm{~ns}$ & $0.039 \mathrm{~ns}$ & $0.182 \mathrm{~ns}$ & $0.053 \mathrm{~ns}$ & $0.113 \mathrm{~ns}$ & $3.5 \mathrm{~ns}$ & $11.34 \mathrm{~ns}$ & $108.5 \mathrm{~ns}$ \\
\hline$a \times b$ & 6 & $151.0 * *$ & $121.3^{* *}$ & $9.6^{* *}$ & $0.493 \mathrm{~ns}$ & $6.6^{* *}$ & $74.2 * *$ & $70.4 * *$ & $165.5 * *$ & $231.5 * *$ \\
\hline $\mathrm{P} \times \mathrm{a} \times \mathrm{b}$ & 6 & $4.59 \mathrm{~ns}$ & $18.99 \mathrm{~ns}$ & $0.163 \mathrm{~ns}$ & $0.103 \mathrm{~ns}$ & $0.048 \mathrm{~ns}$ & $1.4 \mathrm{~ns}$ & $28.2 *$ & $6.87 \mathrm{~ns}$ & $430.7 \mathrm{~ns}$ \\
\hline error & 36 & 9.64 & 18.35 & 1.18 & 0.395 & 0.636 & 6.83 & 10.9 & 12.23 & 187.3 \\
\hline $\mathrm{c}$ & 1 & $84.7 * *$ & $114.7 * *$ & $49.1 * *$ & $1.5^{* *}$ & $24.0 * *$ & $123.1 * *$ & $332.4 * *$ & $109.4 * *$ & $654.3 * *$ \\
\hline $\mathrm{P} \times \mathrm{c}$ & 1 & $8.03 \mathrm{~ns}$ & $1.13 \mathrm{~ns}$ & $0.012 \mathrm{~ns}$ & $0.020 \mathrm{~ns}$ & $0.295 \mathrm{~ns}$ & $0.941 \mathrm{~ns}$ & $3.4 \mathrm{~ns}$ & $12.87 \mathrm{~ns}$ & $121.2 \mathrm{~ns}$ \\
\hline $\mathrm{a} \times \mathrm{c}$ & 2 & $79.3 * *$ & $26.3 \mathrm{~ns}$ & $14.2 * *$ & $0.758^{*}$ & $9.8 * *$ & $120.5^{* *}$ & $81.4 * *$ & $87.9 \mathrm{~ns}$ & $221.2 \mathrm{~ns}$ \\
\hline $\mathrm{P} \times \mathrm{a} \times \mathrm{c}$ & 2 & $0.313 \mathrm{~ns}$ & $0.102 \mathrm{~ns}$ & $0.404 \mathrm{~ns}$ & $0.018 \mathrm{~ns}$ & $0.218 \mathrm{~ns}$ & $0.021 \mathrm{~ns}$ & $20.3 * *$ & $1.213 \mathrm{~ns}$ & $108.6 \mathrm{~ns}$ \\
\hline $\mathrm{b} \times \mathrm{c}$ & 3 & $124.2^{* *}$ & $88.9 * *$ & $16.4^{* *}$ & $7.3^{* *}$ & $4.2 * *$ & $13.4^{*}$ & $21.7 * *$ & $232.2 \mathrm{~ns}$ & $88.9 \mathrm{~ns}$ \\
\hline $\mathrm{P} \times \mathrm{b} \times \mathrm{c}$ & 3 & $0.866 \mathrm{~ns}$ & $12.4 \mathrm{~ns}$ & $0.164 \mathrm{~ns}$ & $0.136^{* *}$ & $0.027 \mathrm{~ns}$ & $0.741 \mathrm{~ns}$ & $4.2 \mathrm{~ns}$ & $2.346 \mathrm{~ns}$ & $78.4 \mathrm{~ns}$ \\
\hline $\mathrm{a} \times \mathrm{b} \times \mathrm{c}$ & 6 & $116.7 * *$ & $97.8 * *$ & $5.4 * *$ & $3.5 * *$ & $3.1 * *$ & $8.5 \mathrm{~ns}$ & $51.1 * *$ & $187.6 \mathrm{~ns}$ & $112.0 \mathrm{~ns}$ \\
\hline Error & 48 & 10.71 & 14.3 & 0.547 & 0.212 & 0.473 & 4.35 & 4.4 & 12.65 & 67.3 \\
\hline C.V $(\%)$ & - & 15.5 & 8.7 & 4.7 & 9.7 & 6.2 & 9.0 & 3.7 & 11.2 & 12.3 \\
\hline
\end{tabular}

*, ** and ns significant at 5\%,1\% and no significant, respectively 


\section{Electrolytes leakage}

The results (Table 3) showed that the maximum electrolyte leakage $(38.3 \%)$ was related to severe water deficit stress treatment without any foliar application. The minimum value was observed when no water deficit stress was imposed and $150 \mathrm{~g} \mathrm{ha}^{-1}$ seaweed extract was applied (Table 4). The interaction between water deficit stress and salicylic acid showed that the maximum electrolyte leakage $(31.3 \%)$ was monitored under severe water deficit stress and salicylic acid foliar application treatments. By contrast, the minimum value $(17.3 \%)$ was achieved when no water deficit stress was induced but salicylic acid was applied on the plants (Table 5). The interaction between seaweed and salicylic acid indicated that the maximum electrolyte leakage (29.3\%) was related to control treatment whereas the minimum value (17.2\%) was observed when $150 \mathrm{~g} \mathrm{ha}^{-1}$ seaweed extract and salicylic acid were applied (Table 6).

Table 4. Interaction between water deficit stress and seaweed extract

\begin{tabular}{|c|c|c|c|c|}
\hline \multicolumn{2}{|c|}{ Treatments } & Yield & Proline & Electrolyte leakage \\
\hline \multirow{4}{*}{$a_{1}$} & $\mathrm{~b}_{1}$ & $1902.2 b c$ & $79 k$ & $21.17 \mathrm{~cd}$ \\
\hline & $\mathrm{b}_{2}$ & $2090.6 b$ & $79.6 \mathrm{~h}$ & $19.17 \mathrm{de}$ \\
\hline & $b_{3}$ & $2343.3 \mathrm{a}$ & $82.2 \mathrm{~h}$ & $16.35 \mathrm{fg}$ \\
\hline & $\mathrm{b}_{4}$ & $2176.6 \mathrm{ab}$ & $87.6 \mathrm{~h}$ & $16 \mathrm{~g}$ \\
\hline \multirow{4}{*}{$\mathrm{a}_{2}$} & $\mathrm{~b}_{1}$ & $1208.1 \mathrm{de}$ & $89.5 b$ & $28.03 b$ \\
\hline & $b_{2}$ & $1408.8 \mathrm{~d}$ & $98.8 \mathrm{ef}$ & $21.79 \mathrm{c}$ \\
\hline & $b_{3}$ & $1592.2 \mathrm{~cd}$ & $102.2 \mathrm{cde}$ & $20.41 \mathrm{cde}$ \\
\hline & $\mathrm{b}_{4}$ & $1790.6 \mathrm{c}$ & $108.6 \mathrm{~d}$ & $18.29 \mathrm{ef}$ \\
\hline \multirow{4}{*}{$\mathrm{a}_{3}$} & $\mathrm{~b}_{1}$ & $902.5 \mathrm{~h}$ & $110.5 \mathrm{~cd}$ & $38.28 \mathrm{a}$ \\
\hline & $\mathrm{b}_{2}$ & $1090.3 \mathrm{~g}$ & $121.4 \mathrm{~d}$ & $28.03 b$ \\
\hline & $\mathrm{b}_{3}$ & $1132.4 \mathrm{fg}$ & $123.2 \mathrm{fg}$ & $28.91 b$ \\
\hline & $\mathrm{b}_{4}$ & $1200.2 \mathrm{de}$ & $111.2 \mathrm{e}$ & $21.72 \mathrm{c}$ \\
\hline
\end{tabular}

Means with the same letter are not significantly different from each other $(\mathrm{P}>0.05$ ANOVA followed by DMRT).

Treatment a drought stress at 3 levels.

Treatment of algae $b$ at 4 levels.

Table 5. Interaction between water deficit stress and salicylic acid

\begin{tabular}{c|c|c}
\hline \multicolumn{2}{c|}{ Treatments } & Electrolyte leakage \\
\hline \multirow{2}{*}{$\mathrm{a}_{1}$} & $\mathrm{c}_{1}$ & $17.29 \mathrm{f}$ \\
& $\mathrm{c}_{2}$ & $19.05 \mathrm{e}$ \\
\hline \multirow{2}{*}{$\mathrm{a}_{2}$} & $\mathrm{c}_{1}$ & $23.69 \mathrm{c}$ \\
& $\mathrm{c}_{2}$ & $20.57 \mathrm{~d}$ \\
\hline \multirow{2}{*}{$\mathrm{a}_{3}$} & $\mathrm{c}_{1}$ & $31.33 \mathrm{a}$ \\
& $\mathrm{c}_{2}$ & $27.14 \mathrm{~b}$ \\
\hline
\end{tabular}

Means with the same letter are not significantly different from each other $(\mathrm{P}>0.05$ ANOVA followed by DMRT).

Treatment a drought stress at 3 levels.

Salicylic acid treatment at 2 levels. 
Table 6. Interaction between seaweed extract and salicylic acid

\begin{tabular}{c|c|c}
\hline \multicolumn{2}{c|}{ Treatments } & Electrolyte leakage \\
\hline \multirow{2}{*}{$\mathrm{b}_{1}$} & $\mathrm{c}_{1}$ & $29.27 \mathrm{a}$ \\
& $\mathrm{c}_{2}$ & $29.05 \mathrm{a}$ \\
\hline \multirow{2}{*}{$\mathrm{b}_{2}$} & $\mathrm{c}_{1}$ & $23.80 \mathrm{~b}$ \\
& $\mathrm{c}_{2}$ & $22.20 \mathrm{c}$ \\
\hline \multirow{2}{*}{$\mathrm{b}_{3}$} & $\mathrm{c}_{1}$ & $23.21 \mathrm{bc}$ \\
& $\mathrm{c}_{2}$ & $20.56 \mathrm{~d}$ \\
\hline \multirow{2}{*}{$\mathrm{b}_{4}$} & $\mathrm{c}_{1}$ & $20.13 \mathrm{~d}$ \\
& $\mathrm{c}_{2}$ & $17.22 \mathrm{e}$ \\
\hline
\end{tabular}

Means with the same letter are not significantly different from each other $(\mathrm{P}>0.05$ ANOVA followed by DMRT).

Treatment of algae $b$ at 4 levels.

Salicylic acid treatment at 2 levels.

Under abiotic stresses, such as salinity, drought, high and low temperatures, plants produce reactive oxygen species, molecules which result in oxidative stress through affecting cellular components and plant metabolism. The reactive oxygen species cause considerable damages to the cells lipid membrane and lead to dis-organisation of the lipid matrix (membrane fluidisation), which in turn decrease cell permeability. Therefore, maintaining cell membrane integrity has an important role in increasing stress resistance (Shim et al., 2003). The effect of salicylic acid on plant growth is mainly due to increased cell division in meristem areas and cell growth. Salicylic acid may also impose its effects through other plant hormones (Shakirova et al., 2003).

\section{Chlorophyll a}

The results showed that the main effect of water deficit stress, seaweed extract and salicylic acid and some interactions between them were significant on chlorophyll a concentration (Table 3). The maximum chlorophyll a concentration $\left(15.15 \mathrm{mg} \mathrm{g} \mathrm{FW}^{-1}\right)$ was obtained when $150 \mathrm{~g}$ ha ${ }^{-1}$ seaweed extract was applied to non-stressed plants. By contrast, the minimum value $\left(8.43 \mathrm{mg} \mathrm{g} \mathrm{FW}^{-1}\right)$ was recorded under severe water deficit stress and application of $50 \mathrm{~g} \mathrm{ha}^{-1}$ seaweed extract (Table 7). In this study, water deficit stress reduced photosynthetic pigments content (chlorophyll and carotenoid). Reduction in photosynthetic pigments under water deficit stress can be attributed to the destruction of chloroplast and photosynthetic apparatus, photo-oxidation of chlorophyll, degradation of precursors of chlorophyll and the suppression of chlorophyll biosynthesis as well as the activation of chlorophyll degrading enzymes and finally hormonal disorders (Orcutt and Nilsen, 2000). However, accumulation of sodium and chloride ions in leaves under salt stress condition also has a negative effect on chlorophyll concentration. Additionally, stress disrupts absorption of certain essential elements such as iron and magnesium, which are essential for chlorophyll synthesis (Neocleous and Vasilakakis, 2007). Lipoxygenase has been reported as one of the enzymes involved in chlorophyll catabolism, while lipoxygenase is one of the enzymes involved in lipid peroxidation too (Farooq et al., 2009). Amino acid and seaweed extract foliar application could significantly increase plant height, photosynthetic pigments, potassium content, 
phosphorus content, and yield, fresh and dry weight in celery. Seaweed extracts contain large amounts of cytokines, auxins and betaine that increase chlorophyll content of leaves (Shehata et al., 2011).

Table 7. Interaction between water deficit stress, seaweed extract and salicylic acid

\begin{tabular}{|c|c|c|c|c|c|c|c|}
\hline \multicolumn{3}{|c|}{ Treatments } & Carotenoid & Anthocyanin & Total chlorophyll & $\begin{array}{c}\text { Chlorophyll } \\
\text { b }\end{array}$ & $\begin{array}{c}\text { Chlorophyll } \\
\text { a }\end{array}$ \\
\hline \multirow{8}{*}{$\mathrm{a}_{1}$} & & & $14.65 \mathrm{i}$ & $39.37 \mathrm{fg}$ & $12.70 \mathrm{mn}$ & $3.65 \mathrm{klm}$ & $9.04 \mathrm{ij}$ \\
\hline & & $\mathrm{c} 2$ & $14.26 \mathrm{i}$ & $33.34 \mathrm{i}$ & $18.28 \mathrm{ef}$ & $5.97 b$ & $12.26 \mathrm{f}$ \\
\hline & & $\mathrm{c} 1$ & 19.22defgh & $28.34 \mathrm{j}$ & 15.36hi & $5.36 \mathrm{~cd}$ & $9.60 \mathrm{i}$ \\
\hline & $v_{2}$ & $\mathrm{c} 2$ & 27.22ab & $40.89 \mathrm{efg}$ & $17.11 \mathrm{~g}$ & 4.41fghi & $12.55 \mathrm{f}$ \\
\hline & & $\mathrm{c} 1$ & 17.35fghi & $48.02 \mathrm{~cd}$ & $18.64 \mathrm{ef}$ & $5.04 \mathrm{de}$ & $13.32 \mathrm{de}$ \\
\hline & 03 & c2 & $15.08 \mathrm{hi}$ & $45.12 \mathrm{cde}$ & $19.69 \mathrm{~cd}$ & $6.04 b$ & $13.42 \mathrm{~cd}$ \\
\hline & & $\mathrm{c} 1$ & 19.67defg & $53.42 \mathrm{ab}$ & $20.33 b c$ & $6.10 \mathrm{ab}$ & $14.05 \mathrm{bcd}$ \\
\hline & $0_{4}$ & $\mathrm{c} 2$ & 16.11ghi & $49.29 b c$ & $21.30 \mathrm{a}$ & $5.70 \mathrm{bc}$ & $15.15 \mathrm{a}$ \\
\hline \multirow{8}{*}{$\mathrm{a}_{2}$} & & $\mathrm{c} 1$ & $23.56 \mathrm{bcd}$ & $43.27 \mathrm{def}$ & $11.92 n$ & $3.311 \mathrm{~m}$ & $8.94 \mathrm{ij}$ \\
\hline & $v_{1}$ & $\mathrm{c} 2$ & $24.25 b c$ & 40.62efgh & $14.90 \mathrm{ij}$ & 4.25hij & $10.68 \mathrm{~h}$ \\
\hline & & $\mathrm{c} 1$ & $29.48 \mathrm{a}$ & $48 \mathrm{~cd}$ & $13.14 \mathrm{~lm}$ & $4.04 \mathrm{ijk}$ & $9.61 \mathrm{i}$ \\
\hline & $v_{2}$ & $\mathrm{c} 2$ & $18.11 \mathrm{efghi}$ & $47.98 \mathrm{~cd}$ & $13.90 \mathrm{kl}$ & $4.95 \mathrm{def}$ & $8.79 \mathrm{ij}$ \\
\hline & & $\mathrm{c} 1$ & $21.03 \mathrm{cdef}$ & $54.52 \mathrm{a}$ & $15.99 \mathrm{~h}$ & 4.53efghi & $12.00 \mathrm{fg}$ \\
\hline & 05 & $\mathrm{c} 2$ & 17.11fghi & $48.80 \mathrm{c}$ & $17.76 \mathrm{fg}$ & $5.22 \mathrm{~cd}$ & $12.55 \mathrm{ef}$ \\
\hline & & $\mathrm{c} 1$ & 20.91cdef & $56.21 \mathrm{c}$ & 20.74ab & $6.63 \mathrm{a}$ & $14.20 \mathrm{bc}$ \\
\hline & & c2 & 17.75fghi & $55.61 \mathrm{a}$ & 19.06de & 4.38fghi & $14.66 \mathrm{ab}$ \\
\hline \multirow{8}{*}{$a_{3}$} & & $\mathrm{c} 1$ & 22.40cde & $39.86 \mathrm{fg}$ & $12.12 n$ & $3.14 \mathrm{~m}$ & $8.75 \mathrm{ij}$ \\
\hline & & c2 & $29.09 \mathrm{a}$ & 33.67hi & $12.77 \mathrm{mn}$ & $3.73 \mathrm{jkl}$ & $9.07 \mathrm{ij}$ \\
\hline & & $\mathrm{c} 1$ & 17.32fghi & $39.24 \mathrm{fg}$ & $12.69 \mathrm{mn}$ & 4.34fghi & $8.43 \mathrm{j}$ \\
\hline & & $\mathrm{c} 2$ & $23.55 \mathrm{bcd}$ & $33.32 \mathrm{i}$ & $13.081 \mathrm{~m}$ & 4.37fghi & $8.90 \mathrm{ij}$ \\
\hline & & $\mathrm{c} 1$ & $29.75 \mathrm{a}$ & $39.85 \mathrm{fg}$ & $14.42 \mathrm{jk}$ & 4.76defgh & $9.60 \mathrm{i}$ \\
\hline & 03 & $\mathrm{c} 2$ & $22.38 \mathrm{cde}$ & $38.03 \mathrm{gh}$ & $13.78 \mathrm{kl}$ & 4.28ghij & $9.55 \mathrm{i}$ \\
\hline & & $\mathrm{c} 1$ & $27.54 \mathrm{ab}$ & $41.55 \mathrm{efg}$ & 15.39hi & 4.90defgh & $11.19 \mathrm{gh}$ \\
\hline & $\mathrm{O}_{4}$ & c2 & 19.53defg & $43.57 \mathrm{def}$ & $15.81 \mathrm{hi}$ & $4.92 \mathrm{def}$ & $10.96 \mathrm{~h}$ \\
\hline
\end{tabular}

Means with the same letter are not significantly different from each other ( $\mathrm{P}>0.05$ ANOVA followed by DMRT).

Treatment a drought stress at 3 levels.

Treatment of algae $b$ at 4 levels.

Salicylic acid treatment at 2 levels.

\section{Chlorophyll b}

This study results showed that the main effect of water deficit stress, seaweed extract and salicylic acid and some interactions between them were significant on chlorophyll $b$ concentration (Table 3). The maximum chlorophyll b concentration $\left(6.63 \mathrm{mg} \mathrm{g} \mathrm{FW}^{-1}\right)$ was obtained when $150 \mathrm{~g} \mathrm{ha}^{-1}$ seaweed extract and salicylic acid were applied on plants grown under mild water deficit stress. By contrast, the minimum value $\left(3.14 \mathrm{mg} \mathrm{g} \mathrm{FW}^{-}\right.$ 
${ }^{1}$ ) was related to severe water deficit stress without seaweed or salicylic acid application (Table 7). Salicylic acid application on plants increases chlorophyll (as one of the main components of the photosynthetic apparatus affecting dry weight) and carotenoid content in control and stressed plants, indicating the ability of salicylic acid to improve plant growth. Similarly to the results of this experiment, it has been reported that salicylic acid increased chlorophyll and carotenoid content in barley, wheat, spinach, canola, tomato and pea (El-Tayeb, 2005). Increase in fresh weight, dry weight, root length, stem length and chlorophyll content on the account of seaweed extract has been reported previously (Sridhar and Rengasami, 2011).

\section{Total chlorophyll}

The results showed that the main effect of water deficit stress, seaweed extract and salicylic acid and some interactions between them were significant on total chlorophyll concentration (Table 3). The maximum total chlorophyll concentration $\left(21.3 \mathrm{mg} \mathrm{g} \mathrm{FW}^{-}\right.$ ${ }^{1}$ ) was obtained when $150 \mathrm{~g} \cdot \mathrm{ha}^{-1}$ seaweed extract was applied on plants grown under no water deficit stress. By contrast, the minimum value $\left(11.9 \mathrm{mg} \mathrm{g} \mathrm{FW}^{-1}\right)$ was related to mild water deficit stress without seaweed or salicylic acid application (Table 7). Seaweed-based fertilizers improve plants growth by providing more nitrogen, phosphorus, and potassium, as well as supplying micronutrients and secondary metabolites (Karthick et al., 2013). Studies on cucumber, after using seaweed extracts (red and green algae) indicated that fresh and dry weight and leaf area increased probably due to increased nitrogen concentration and improving soil physical conditions through providing more energy for microorganisms helps to improve availability and absorption of mineral nutrients. Increase in yield may also be related to some nutritional elements, especially iron, zinc and manganese in compost and potassium, calcium, magnesium, sulfur, and iron in seaweed extract. These elements can stimulate vegetative growth, chlorophyll biosynthesis, and photosynthesis, which in turn affect flowering and fruit production (Ahmed and Shalaby, 2012).

\section{Anthocyanin}

The results indicated that the main effect of water deficit stress, seaweed extract and salicylic acid and some interactions between them were significant on anthocyanin concentration (Table 3). The maximum anthocyanin concentration $\left(56.2 \mathrm{mmol} \mathrm{g} \mathrm{FW}^{-1}\right)$ was obtained when $150 \mathrm{~g} \cdot \mathrm{ha}^{-1}$ seaweed extract and salicylic acid were applied on plants grown under mild water deficit stress. By contrast, the minimum value $(28.3 \mathrm{mmol} \mathrm{g}$ $\mathrm{FW}^{-1}$ ) was related to $50{\mathrm{~g} . h a^{-1}}^{-}$seaweed extract and salicylic acid treatment on plants grown under no water deficit stress (Table 7). Flavonoids, flavones, and anthocyanins have anti-oxidant properties and it has been proven that their production and gene expression increase under stress conditions (Tang et al., 2006). In general, it has been shown that seaweeds affect antioxidant activity and chemical composition of plants grown under environmental stresses (Van Alstyne, et al., 2007).

\section{Carotenoids}

The results indicated that the main effect of water deficit stress, seaweed extract and salicylic acid and some interactions between them were significant on carotenoids content (Table 3). The maximum carotenoids content $\left(29.7 \mathrm{mg} \mathrm{g} \mathrm{FW}^{-1}\right)$ was obtained when 100 g.ha ${ }^{-1}$ seaweed extract and salicylic acid were applied on plants grown under 
severe water deficit stress. By contrast, the minimum value $\left(14.3 \mathrm{mg} \mathrm{g} \mathrm{FW}^{-1}\right)$ was related to non-stressed plants without any seaweed extract or salicylic acid application (Table 7). The induction of carotenoid biosynthesis under stress conditions might be due to their protective role in photosynthetic systems. These pigments are responsible for neutralizing reactive oxygen species and preventing lipid peroxidation and ultimately oxidative stress. Carotenoids release large amounts of energy from photosystems (I) and (II) in the form of heat or chemical reactions which can maintain chloroplast membranes (Koyro, 2006). In a study carried out by Sivasankari et al. (2006), application of $20 \%$ seaweed liquid fertilizer (SLF) could increase shoot length, root length, fresh weight, dry weight, chlorophyll, carotenoid, shoots and root protein content, shoots and root amino acids content, alpha amylase and beta amylase activity. The improvement of growth parameters due to salicylic acid might be due to its effect on the photosynthetic apparatus, photosynthesis rate, rubisco enzyme activity, photosynthetic pigments concentration, stomatal conductance, antioxidant defense system, reduction of oxidative stress and ion leakage. An increase in cell membrane integrity, nitrogen metabolism, and mineral nutrition are also mentioned in various studies (El-Tayeb, 2005).

\section{Proline}

The results indicated that the main effect of water deficit stress, seaweed extract and salicylic acid and some interactions between them were significant on proline content (Table 3). The minimum proline content $\left(79 \mathrm{mg} \mathrm{g} \mathrm{FW}^{-1}\right.$ ) was obtained when no seaweed extract was applied on plants grown under no water deficit stress. By contrast, the maximum value $\left(123.2 \mathrm{mg} \mathrm{g} \mathrm{FW}^{-1}\right)$ was related to severe water deficit plants treated with 100 g.ha- ${ }^{-1}$ seaweed extract (Table 4). In all stress levels, application of 100 or 150 g.ha ${ }^{-1}$ seaweed extract resulted in proline accumulation. Increasing in proline accumulation on the account of a particular treatment, such as seaweed extract, leads to increased resistance to drought stress, followed by higher yields (Koyro, 2006). Water stress cause chlorophyll degradation, and glutamate, which is a precursor of chlorophyll and proline, is transformed into proline, resulting in a reduction in the chlorophyll content (Lawlor and Cornic, 2009). Proline is known as an osmotic regulator that increases in response to salinity stress. One of the most important mechanisms in higher plants grown under salinity conditions is the accumulation of compounds such as proline. Proline accumulation is a primary defense response to maintaining osmotic pressure in cells. It has been reported that proline has a key role in osmotic regulation, protection of cell structures and neutralization of reactive oxygen species as well as malondialdehyde and the ascorbate peroxidase (Ashraf and Foolad, 2007). Another reason to increase the proline content in plants grown under water deficit stress is chlorophyll degradation. As a result, the concentration of these substances increases under stress conditions. In this study, in the plants grown under water deficit stress, the total chlorophyll content decreased whereas proline leaf concentration increased, which is consistent with the above hypothesis.

\section{Seed yield}

The results indicated that the main effect of water deficit stress, seaweed extract and salicylic acid and interaction between water deficit stress and seaweed extract was significant on seed yield (Table 3). The maximum seed yield (2343.3 $\left.\mathrm{kg} \mathrm{ha}^{-1}\right)$ was obtained when $100 \mathrm{~g} \mathrm{ha}^{-1}$ seaweed extract was applied on non-stressed plants. By 
contrast, the minimum seed yield $\left(90.2 .5 \mathrm{~kg} \mathrm{ha}^{-1}\right)$ was related to severe water deficit plants without seaweed extract application. In all stress levels, application of 100 or 150 $\mathrm{g} \mathrm{ha}^{-1}$ seaweed extract could increase seed yield. Numerous studies have shown the positive effects of seaweed and biological fertilizers on growth and yield of plants. It is likely that seaweed extract application increases, absorption and storage of nutrients in different parts of the plants, including leaves and stems, which in turn results in increased yield (Ahmad and Khalili, 2006). In addition, it seems that increase in stress, reduces plant growth and nutrient content. Therefore, reduction in vegetative growth due to the reduction of osmotic potential, reproductive growth and finally seed yield is not surprising. Environmental stresses decrease water uptake, transpiration and stomatal closure, which lead to a decrease in growth (Ben-Asher et al., 2006). The results have shown that the application of green and red seaweed extracts and commercial extract of seaweed with compost, improve vegetative growth, dry and fresh weight and yield of cucumber (Ahmed and Shalaby, 2012). Increase in fresh and dry weight might be due to nitrogen availability and improving soil physical properties as well as improved oil microorganisms' activity on the account of seaweed application. Increase in yield may also be related to some nutritional elements, especially iron, zinc and manganese in compost and potassium, calcium, magnesium, sulfur and iron in seaweed extract. These elements can stimulate vegetative growth, chlorophyll biosynthesis and photosynthesis, which in turn affect flowering and fruit production (Ahmed and Shalaby, 2012). Seaweed-based fertilizers improve plant growth through providing more nitrogen, phosphorus and potassium, as well as supplying micronutrients and secondary metabolites. In a study carried out by (Ahmed and Shalaby, 2012) seaweed extract application could increase vegetative growth and fruit yield of cucumber.

\section{Conclusion}

Application of salicylic acid and seaweed extract by increasing the activity of antioxidant enzymes (including catalase, ascorbate peroxidase and peroxidase) and plant proline, have an important role in the reduction of oxygen radicals (hydroxyl, peroxide hydrogen, and super oxide) that were produced due to water stress. Using salicylic acid and seaweed extract enhance the biosynthesis and protection of photosynthetic pigments under water stress and result in higher chlorophyll concentration. Thus it seems that foliar application of salicylic acid under water stress can promote water saving which is very critical at current situation of water scarcity for agriculture and can mitigate the damages of water stress which may finally result in higher crop yield.

\section{REFERENCES}

[1] Ahmad, A. J., Khalili, M. (2006): Effect of low irrigation on yield and yield components of maize in Miandoab region. - Iranian Journal of Water Research 1(1): 17-28.

[2] Ahmed, Y. M., Shalaby, E. A. (2012): Effect of Different Seaweed Extracts and Compost on Vegetative Growth, Yield and Fruit Quality of Cucumber. - Journal of Horticultural Science \& Ornamental Plants 4(3): 235-240.

[3] Ashraf, M., Foolad, M. R. (2007): Role of glycine betaine and Proline in Improving Plant Abiotic Stress Resistance. - Environmental and Experimental Botany: 206-216. 
[4] Bai, L. P., Sui, F. G., Ge, T. D., Sun, Z. H., Lu, Y. Y., Zhou, G. S. (2006): Effect of soil drought stress on leaf water status, membrane permeability and enzymatic antioxidant system of maize. - Soil Science Society of China 16(3): 326-332.

[5] Bates, L. S., Waldren, R. P., Teare, I. D. (1973): Rapid determination of free proline for water stress studies. - Plant and Soil 39: 205-207.

[6] Ben-Asher, J., Tsuyuki, I., Bravdo, B. A., Sagih, M. (2006): Irrigation of grapevines with saline water. I. Leaf area index, stomatal conductance, transpiration and photosynthesis. Agricultural Water Management 83: 13-21.

[7] Diaz-Perez, J. C., Shackel, K. A., Sutter, E. G. (2006): Relative water content. - Ann of Bot. 97(1): 85-96.

[8] El-Tayeb, M. A. (2005): Response of barley grain to the interactive effect of salinity and salicylic acid. - Plant Growth Regul 42: 215-224.

[9] Erulan, V., Thirumaran, G., Soundarapandian, P., Ananthan, G. (2009): Studies on the effect of Sargassum polycystum (C. agardh, 1824) extract on the growth and biochemical composition of Cajanus cajan (L.) Mill sp. - American-Eurasian Journal of Agricultural and Environmental Sciences 6(4): 392-399.

[10] FAO. (2010): FAOSTAT. Available in http://faostat.fao.org/ [28 May 2010].

[11] Farooq, M., Wahid, A., Kobayashi, N., Fujita, D., Basra, S. M. A. (2009): Plant drought stress: effects, mechanisms and management. - Agronomy for sustainable development 29(1): 185-212.

[12] Flint, H. L., Boyce, B. R., Beattie, D. J. (1967): Index of injury drought a useful expression of freezing injury to plant tissues as determined by the electrolytic method. Can. J. Plant Sci. 47: 229-230.

[13] Hayat, S., Ahmad, A. (2007): Salicylic Acid: plant hormone. - Springer, p. 97-99.

[14] Hosseini, N. M. (2008): Agriculture and Cereal Production. - Mashhad University Press (In Persian).

[15] Hussain, M., Farooq, M., Malik, M. A. (2008): Glycinebetaine and salicylic acid application improves the plant water relations, water use efficiency and yield of sunflower under different planting methods. - Proceedings of 14th Australian Agronomy Conference, Adelaide, SA, Australia.

[16] Kaoaua, M. E., Chernane, H. H., Benaliat, A., Neamallah, L. (2013): Seaweed liquid extracts effect on salvia officinalis growth, biochemical compounds and water deficit tolerance. - African Journal of Biotechnology 72(28): 4481-4589.

[17] Karthick, N., Selvakumars, S., Umamaheswari, S. (2013): Effect of three different seaweed liquid fertilizers and a chemical liquid fertilizer on the growth and histopathological parameters of Eudrilus Eugeniae (Haplotaxida: Eudrilidae Global). Journal of Bio-Science and Biotechnology 2(2): 253-259.

[18] Kovacik, J., Klejdus, B., Babula, P., Jarosova, M. (2014): Variation of antioxidants and secondary metabolites in nitrogen-deficient barely plants. - Journal of Plant Physiology 171: 260-268.

[19] Koyro, H. W. (2006): Effect of salinity on growth, photosynthesis, water relations and solute composition of potential cash crop halophyte (Plantago coronopus L.). - Environ Exp Bot 56: 136-149.

[20] Lawlor, M. H., Cornic, U. S. (2009): Manganese efficiency and manganese-uptake kinetics of raya (Brassica juncea), Weat (Triticum aestivum), and oat (Avena sativa) grown in nutrient solution and soil. - J. Plant Nutrition. Soil Sci. 172: 425-434.

[21] Lichtenthaler, H. K., Wellburn, A. R. (1983): Determination of total carotenoids and chlorophyll a and b of leaf extract in different solvents. - Biol. Soc. Trans. 11: 591-592.

[22] Neocleous, D., Vasilakakis, M. (2007): Effects of $\mathrm{NaCl}$ stress on red raspberry (Rubus idaeus L. "Autumn Bliss"). - Scientia Horticulturae 112: 282-289.

[23] Orcutt, D. M., Nilsen, E. T. (2000): The physiology of plants under stress, soil and biotic factors. - John Wiley and Sons, New York. pp: 177-235. 
[24] Porra, R. J. (2002): The chequered history of the development and use of simultaneous equations for the accurate determination of chlorophylls a and b. - Photosynthesis Res. 73: $149-156$.

[25] Ramroudi, M., Khamar, A. R. (2013): Interaction of salicylic acid spraying and irrigation treatments on some properties of quantitative, qualitative and basil osmotic regulator. Journal Applied Research Eco Physiology plants 1(1): 19-32.

[26] Rehman, Z. U., Shah, W. H. (2004): Domestic processing effects on some insoluble dietary fiber components of various food legumes. - Food Chemistry 87: 613-617.

[27] Shakirova, F. M., Sakhabutdinova, A. R., Bezrukova, M. V., Fathutdinova, R. A., Fathutdinova, D. R. (2003): Changes in hormonal status of wheat seedlings induced by salicylic acid and salinity. - Plant Sci 164: 317-22.

[28] Shehata, S. M., Abdel-Azem, H. S., El-Yazied, A. A., El-Gizawy A. M. (2011): Effect of foliar spraying with amino acids and seaweed extract on growth chemical constitutes, yield and its quality of celeriac plant. - European Journal of Scientific Research 58(2): 257-265.

[29] Shim, I. S., Momose, Y., Yamamoto, A., Kim, D. W., Usui, K. (2003): Inhibition of catalase activity by oxidative stress and its relationship to salicylic acid accumulation in plants. - Plant Growth Regul 39: 285-92.

[30] Sivasankari, S., Venkatesalu, V., Anantharaj, M., Chandrasekaran, M. (2006): Effect of seaweed extracts on the growth and biochemical constituents of Vigna sinensis. Bioresource Technology 97: 1745-1751.

[31] Sridhar, S., Rengasamy, R. (2011): Potential of seaweed liquid fertilizers (SLFS) on some agricultural crop with special reference to protein profile of seedlings. - International Journal Development Resarch 7: 55-57.

[32] Tang, L., Kwon, S. Y., Kim, S. H., Kim, J. S., Choi, J. S., Cho, K. Y., Sung, C. K., Kwak, S. S., Lee, H. S. (2006): Enhanced tolerance of transgenic potato plants expressing both superoxide dismutase and ascorbate peroxidase in chloroplasts against oxidative stress and high temperature. - Plant Cell Rep. 25(12): 1380-1386.

[33] Van Alstyne, K. L., Koellermeier, L., Nelson, T. A. (2007): Spatial variation in dimethylsulfoniopropionate (DMSP) production in Ul valactuca (Chlorophyta) from the Northeast Pacific. - Marine Biology 150: 1127-1135. 